УДК 94(=112.2)(470.62/.67)»17/19»(049.32)

DOI $10 / 15421 / 312013$

С. Й. Бобилсва,

Н. В. Венгер

Дніпровський науіональний університет імені

Олеся Гончара

\title{
РЕЦЕНЗІЯ \\ НА КНИГУ Т. М. ЧЕРНОВОЇ-ДЬОКЕ «НІМЕЦЬКІ ПОСЕЛЕННЯ НА ПІВНІЧНОМУ КАВКАЗІ РОСІЙСЬКОЇ ІМПЕРІЇ»*
}

Бобилєва С. Й., Венгер Н. В. Рецензія на книгу Т. М. Чернової-Дьоке «Німецькі поселення на Північному Кавказі Російської імперпџ).

У рецензії надається аналіз монографії Т.М. Чернової-Дьоке, присвяченої історії створення, розвитку та руйнації німецькомовних колоній Північного Кавказу. Перебіг подій розглядається до 1941 р. (включаючи депортацію).

Ключові слова: колонізація, депортація, етноси Південного Кавказу.

Бобилева С. И., Венгер Н. В. Рецензия на книгу Т. Н. Черновой-Дьоке «Немецкие поселения на Северном Кавказе Российской империи».

В рецензии предоставлен анализ монографии Т. М. Черновой-Дьоке, посвященной истории создания, развития и разрушения немецкоязычных колоний Северного Кавказа. Исследуются события до 1941 г., включая период депортации.

Ключевые слова: колонизация, депортация, этносы Южного Кавказа.

Bobyleva S. I., Venger N. V. Rezension des Buches von T. N. Tschernowa-Döke «Deutsche Siedlungen im Nordkaukasus des Russischen Imperiums».

Eine Analyse der Monographie von T. N. Tschernowa-Döke zur Geschichte der Entstehung, Existenz und des Verschwindens der deutschsprachigen Kolonien im Nordkaukasus wird vorgestellt. Die Ereignisse vor 1941 - die Zeit der Deportation - werden untersucht.

Schlüsselwörter: Kolonialisierung, Deportation, ethnische Gruppen des Südkaukasus.

Bobileva S. I., Venger N. V. Review of the book by T. N. Chernova-Dyoke «German settlements in the North Caucasus of the Russian Empire».

The review provides an analysis of the monograph by T. N. Chernova-Dyoke, dedicated to the history of the formation, development and disappearance of the German-speaking colonies in the North Caucasus. The events till 1941 (including deportation) are being studied.

Key words: colonization, deportation, ethnic groups of the South Caucasus.

Відтоді як наприкінці $\mathrm{XX}$ ст. історія російських німців втратила статус забороненої теми, вона стала предметом розвідок численної когорти талановитих науковців. Визначилося коло дослідників, які вивчали історичний шлях етнічних німців Російської імперії та СРСР в окремих регіонах: С. Бобилєва, Н. Венгер, О. Безносов, Е. Плесська, М. Костюк, В. Клець, О. Ходченко (Україиа); А. Айсфельд, В. Деннінгхаус, P. Нахтігаль, Д. Мєшков (ФРН); I. Нам,
Т. Смирнова, П. Вібе, Л. Малиновський, Т. Плохотнюк (Російська Федерація); Х. Дік, А. Фрізен, Дж. Стейплз (США і Канада). У межах комплексної проблеми іноземної колонізації виокремилися тематичні напрями ії дослідження: культурне життя та система освіти етнічних німців (I. Черказьянова), їхне духовне та релігійне життя (О. Безносова), вплив військових подій на колоністське суспільство (С. Неліпович). Перелік науковців, що займаються відновленням історичної

\footnotetext{
" Чернова-Дёке Т. Н. Немецкие поселения на Северном Кавказе Российской империи. М., 2020. 224 с.
} 
пам'яті і правди про минуле німецького населення Російської імперії, СРСР та України, а також список досліджуваних ними проблем, можна було б, безперечно, продовжити, на щастя, він дійсно великий. Серед згаданих прізвищ гідне місце займає постать $\mathrm{T}$. М. Чернової-Дьоке - історика, яка народилась у Радянському Союзі (Ставропольський край), закінчила докторантуру в Києві, а нині проживає і продовжує наукову діяльність у ФРН. Як дослідницю ії відрізняє відданість обраній темі. Характерною рисою наукової діяльності Чернової-Дьоке $\epsilon$ регіональний підхід, через призму якого в іiі публікаціях здійснюється комплексний аналіз минулого німецькомовного населення Кавказу.

Наразі Тамара Миколаївна підготувала нову монографію, присвячену історії колонізації Північного Кавказу, вивченню локальної специфіки цих процесів. Чї книга $\epsilon$ логічним продовженням попередньої праці «Немецкие поселения на периферии Российской империи. Кавказ: взгляд сквозь столетие (1818-1917)» (Москва, 2008). У дослідженні, що рецензується, виконується глибокий аналіз політичних особливостей, повсякденних соціально-економічних практик, релігійного життя німецьких колоністів Північного Кавказу. Останній був однісю 3 найбільш проблемних та неспокійних околиць Російської iмперіï.

Для тексту монографії властиві не лише блискучий стиль презентації проблеми, але й глибокий аналітичний аналіз подій, що відбувалися, грунтовна доказова база дослідження. Остання не обмежується архівними матеріалами, але й доповнюється сутнісними відомостями, почерпнутими в періодичній пресі Закавказзя XIX ст. («Северный Кавказ», «Кавказ», «Кубанские областные ведомости»), а також матеріалами центральної російської періодики. У праці пропонується аналіз найважливіших джерел. Зокрема розглядається Маніфест 1785 p., який започаткував іноземну колонізацію Прикавказзя; цитуються акти, зібрані вченими Кавказької археографічної комісії, використовуються матеріали «Кубанських збірок», що видавалися Кубанським статистичним комітетом. Окрім цього, до свого дослідження авторка залучає свідоцтва Кавказького відділу Імператорського російського географічного товариства та матеріали його друкованого органу («Відомості Кавказького відділу Імператорського російського Географічного Товариства»). Цікаві свідоцтва (майже з перших рук) були знайдені автором у багатотомних «Збірниках матеріалів для опису місцевостей і племен Кавказу», в працях місцевих краєзнавців.

Чернова-Дьоке не лише чітко визначила географічні межі свого дослідження, але й, зазначивши специфіку регіону, зауважила на його виключному геостратегічному положенні, яке зробило його центром тяжіння інтересів кількох держав (Російської імперії, Персії (Ірану), Османської імперії (Порти), низки західних країн) та предметом жорстокого військового протиборства. По-суті, Кавказ, подібно до України, був фронтирною територією 3 усіма властивими йй характеристиками. Саме в цьому полягає деяка схожість розвитку колоній цих околиць (за не менш значної різниці їх еволюції!), що опинилися «in between» геополітичних, ситуативностратегічних, локально-територіальних та просто етнонаціональних інтересів. «Плавильний котел», що склався на Кавказі, здійснив важливий вплив як на процес колонізації, так і на подальше життя переселенців.

Принципово важливе завдання авторки полягало в координації іiі матеріалу про німецьких колоністів 3 більш глобальними подіями імперського виміру, що відбувалися в той час у державі. Російська імперія перебувала тоді на етапі націоналізації - формування свого національного проєкту. У праці йдеться не тільки про характер відносин центру імперії 3 іiі етнічною околицею. Все набагато глибше і цікавіше. У цьому випадку ми масмо справу 3 новим прочитанням історії панування Росії в проблемному регіоні, затвердження якого проходило через криваві війни та придушення повстань гірських народів Кавказу. При цьому авторка, зробивши головний акцент на унікальній поліетнічності регіону, глибоких мовних і конфесійних відмінностях народів і етносів, спромоглася показати своєрідність колонізації Північного Кавказу, іi локальну відмінність від того, що відбувалося на інших околицях імперії. Особливий інтерес викликають ті сторінки праці, де розглядаються питання створення унікальної системи централізованого управління регіоном та зміна його адміністративного устрою.

Як і в попередній праці, в тексті зустрічаються історіографічні вкраплення, що дозволяє читачеві не лише зосередитися на дискусійних моментах проблем історії німецьких переселенців, але й побачити нові теми, які ще чекають на своїх дослідників. Наприклад, авторка переконливо показала труднощі, що поставали на шляху первісної колонізації території Північного Кавказу. Зокрема вона підкреслила складне геополітичне становище та тривалу війну Росії з Туреччи- 
ною (Розділ I). Нею доказово обгрунтовано висновок щодо трансформації державної стратегії іноземної колонізації і перехід до організованого переселення вірнопідданих колоністів. Слід звернути увагу на сюжет, пов'язаний з історією Грузій, де йдеться про особливості і1 включення до складу Росії. У цілому всі передмови до розділів мають цілком органічний характер та презентують те вкрай необхідне історичне тло, яке дозволяс краще усвідомити події, що відбувалися.

Вкрай цікавим $\epsilon$ матеріал про стихійну внутрішню міграцію, яка була особливістю регіону, залюднення якого відбувалося переважно за рахунок внутрішньоімперського руху переселенців. Йдеться про колоністів Поволжя, Причорноморських німців та феномен стихійного заснування сел. Досліднишя звертає увагу на заходи влади 3 утримання колоній (с. 75-79), випадки позбавлення статусу колоністів і пільг стосовно самовільних переселенців. Як додаток до цих сюжетів у праці подано статистичний матеріал, де чисельно розмежовуються переселенці 3 Поволжя та Причорномор'я. Зауважимо, що, подібно до Причорноморських територій, процес колонізації частково супроводжувався насильницьким згоном із земель корінних мешканців - горців, що стимулювало їх виїзд за кордон. Близько 500 тис. представників аборигенного населення покинули батьківщину. При цьому авторка звертає увагу на узгодження дін̆ російської влади з Туреччиною доставку транспортних судів у порт.

Як позитивне явище слід зазначити той факт, що Чернова-Дьоке виокремиламенонітів серед інших німецькомовних поселенців (с. 79-89). На початку підрозділу авторка зупинилася на історичних та світоглядних характеристиках, властивих представникам цієї етноконфесії. Вірогідно, що цей, на перший погляд опосередкований, матеріал $\epsilon$ важливим та цікавім для тієї групи читачів, яка не до кінця знайома зі специфікою проблеми дослідження. У роботі вдало показано складнощі природної та соціальногосподарської адаптації в процесі заснування менонітських колоній, придбання ними землі, їхьої селекційної роботи в галузі тваринництва, товарний характер конярства (с. 8999). Розглядаючи питання господарського розвитку менонітських колоній, авторка звертає увагу на прагнення їх мешканців використовувати досягнення тогочасної агронауки, черпаючи знання 3 наукових журналів, застосовуючи новинки сільськогосподарської техніки. Для менонітів, як зазначає автор, було властивим раціональне ставлення до природи, іі використання на свою користь. Йдеться, наприклад, про будівництво каналу, води якого дозволили зрошувати землі та збілышити врожайність (с. 93), формування (майже так, як і на Україні) масивів лісових насаджень на околищях колоній (с. 123-129). Авторка також констатус разючі відмінності рівнів економічного розвитку колоністських господарств і місцевого автохтонного населення.

Застосовуючи унікальний архівний матеріал, дослідниця намагається відтворити події розвитку окремих колоній (Розділ III), ix особливі та спільні риси. Вона зупиняеться на моментах соціального розшарування в поселеннях, що було пов'язано з фактором малоземелля. Саме це ставало головною рушійною силою стихійного переселення: створення стихійних колоній та численного зростання хутірських господарств. На сторінках монографії дослідницею досить докладно розглянуто й форми землеволодіння та землекористування колоністів. Идеться про казенні, приватновласницькі та орендні землі. Аналізуючи господарське життя колоністів, авторка не схильна ідеалізувати їхні стосунки 3 навколишнім населеним, і перш за все горцями. Колоністи неодноразово страждали від набігів інгушів і були інколи змушені змінювати місце розтапування колоній. Такою була своєрідна помста «чужинцям», яких (як горці були впевнені) підтримувала та просувала ненависна їм влада.

Абсолютно самостійним сюжетом у межах розгляду історії колонізації Північного Кавказу виглядають сторінки монографії, на яких розгортаються події «Руху Виходу» 3 Німеччини (с. 105-111). Авторка презентує самі ідеї учасників цього процесу, створює портрет іхнього ідеолога Самуеля Кльотера. Також дослідницею здійснюється досить докладний опис їхього поселення Гнаденбург, фіксується наявність у межах общини елементів соціальної програми. Зокрема згадусться про утворення в колонії дитячого садка. Цікавим моментом, що характеризуе заходи держави зі спонукання колоністів до прийняття російського громадянства, було надання переселеншям пільг в обмін на прийняття підданства.

Мешкаючи у православніи імперії, переселенці намагалися зберігати свої релігійні традиції. У зв'язку 3 цим досліднишя мала приділити увагу духовному життю переселенців (с. 111-123). Нею зазначено діяльність чотирьох євангелічнолютеранських парафій: П'ятигорськоКарраської, Катеринодар-Новоросійської, Ставропольської та Владикавказької. До- 
сить докладно розглянуто окремі сектантські релігійні течії, які були впливовими в колоністському середовищі цього регіону. Останньому значною мірою сприяло дисперсне розселення німців у віддалених сільських громадах регіону, а також брак пасторів. Католики населяли три колонії. І хоча між лютеранами і католиками зберігалися непримиренні протиріччя на релігійному грунті, як зазначає Тамара Миколаївна, конфліктів між ними не спостерігалося. Те ж стосувалося і відносин 3 іншиими релігійними течіями: штундистів, «гюпферів», адвентистів. Про це також свідчила поліконфесійність низки німецьких колоній. Головними рисами в поведіиці та менталітеті німецьких i менонітських поселенців визначаються духовність, релігійність, конфесійний світогляд, майже «пуританська» етика, прихильність рідній мові та національним традиціям.

Цілком успішна господарська практика колоністів привела до появи і розвитку торгово-підприсмницької діяльності (розділ IV). Цьому, як було слушно зазначено авторкою, значною мірою сприяв розвиток залізничного будівництва. Проте залізниці будувалися не стільки 3 міркувань необхідності економічного розвитку регіону, скільки із завдань військово-стратегічного характеру, маючи на меті з'єднати російські землі та Кавказький край і Закавказзя як окремі околиці, чиї кордони були пов'язані 3 проблемними для імперії державами (с. 120).

Стратегічне розташування регіону, майже повсюдна традиція ставлення до іиородпів під час військових конфліктів як до зрадників призвела до того, що за часів Першої світової війни німецькі колоністи опинилися в ролі об'сктів антинімецької кампанії, що проводилася як урядом, так і військовими. Особливе завзяття в цій справі виявив намісник Кавказу Великий князь Микола Миколайович. Авторка послідовно розглядає змістову та політичну суть самих законів, їх вплив на долі колоністів. Певну увагу приділено окремим циркулярам-уточненням, імплементація яких багато в чому погіршувала становище колоністів (с. 154-174).

Важливим для цілісності розуміння проблеми $\epsilon$ звернення дослідниці до подій депортації 1941 р. Вони виявилися своєріднім сумним епілогом у цілому суперечливої, але й небезуспішної історії проживання німецького населення в регіоні. Порушуючи тему відповідальності, обвинувачення в смертях тисяч депортованих дослідниця покладає на тоталітарний режим, який багато в чому наслідував імперські традиції у ставленні до регіону та його населення.

Т. М. Чернова-Дьоке була серед першाих дослідників, які в 1990-х рр. розпочинали вивчення комплексу проблем, пов'язаних з іноземною колонізацією, історією західних національних меншин на теренах Російської імперії, СРСР та у пострадянський період. Як фахівець з Кавказького регіону у своїх монографіях вона створила цілком цілісний образ історичного минулого німецьких поселень околищі. Iї праці також виконали важливу функцію презентації цієї проблеми. Сподіваємося, що результати дослідження Т. М. Чернової надихнуть молодих авторів на подальші наукові пошуки. Ми також щиро рекомендуємо українському читачеві ознайомитися зі змістом наукових праць цієї дослідниці. 